\title{
Influence of titanium and bio-fertilizers on some agronomic and physiological attributes of triticale exposed to cadmium stress
}

\author{
Ghooshchi F.* \\ Department of Agronomy, Varamin- Pishva Branch, Islamic Azad University, Varamin, Iran \\ Received: 03/02/2017, Accepted: 02/03/2017, Available online: 20/10/2017 \\ *to whom all correspondence should be addressed: e-mail: ghooshchi.f@gmail.com
}

\begin{abstract}
To evaluate the effects of titanium and bio-fertilizers on some agronomic and physiological properties of triticale grown in cadmium ( $\mathrm{Cd}$ ) contaminated soil, a glasshouse experiment was conducted based on a completely randomized design with three replications. The treatments were arranged in a $4 \times 4$ factorial experiment with four levels of titanium (control, bulk titanium, $0.01 \%$, and $0.02 \%$ titanium nano-particles) and four levels of bio-fertilizers (no bio-fertilizer, Azotobacter chroococcum, Azospirillum brasilense and Azorhizobium caulinodans). The $\mathrm{Cd}$ contamination increased $\mathrm{Cd}$ accumulation in the leaves and seeds and also enhanced antioxidant enzymes activity. Cadmium stress decreased grain yield, 1000-grain weight and chlorophyll. Titanium nano-particle $(0.02 \%)$ caused the maximum increase in grain yield, 1000-grain weight, leaf $\mathrm{Cd}$, seed $\mathrm{Cd}$, chlorophyll content. Superoxide dismutase (SOD) and catalase (CAT) activity increased due to titanium application but malondialdehyde (MDA) contented decreased. Although, there was no significant difference between control and bulk titanium treatments in terms of SOD activity. The effect of $0.02 \%$ nano-particle in increasing SOD activity was more pronounced than $0.01 \%$ treatment. In addition, CAT activity was more affected by titanium nano-particles than bulk titanium. Furthermore, Azorhizobium increased grain yield, 1000-grain weight, leaf $\mathrm{Cd}$, seed $\mathrm{Cd}$ and chlorophyll while decreased superoxide dismutase and catalase enzyme activity.
\end{abstract}

Keywords: Titanium; triticale; antioxidant enzymes; biofertilizers.

\section{Introduction}

Cadmium ( $\mathrm{Cd}$ ) is a non-essential heavy metal, released into the environment by anthropogenic and non-anthropogenic sources (Sandalio et al., 2001). So far, few studies have been conducted to determine the effect of toxic Cd levels on the uptake and distribution of $\mathrm{Cd}$ in different parts of plants, particularly in the parts used as food or feed. Crop plants growing in high levels of $\mathrm{Cd}$ will show a series of physiological disorders, such as reduction in chlorophyll, sugar and protein content, decrease of photosynthesis and dramatic change of phenol content and related enzyme activities, finally leading to lower yield (Satyakala, 1997).
For instance, Muradoglu et al., (2015) indicated that Cd had negative effect on chlorophyll content. Cadmium induces oxidative stress leading to the overproduction of harmful reactive oxygen species (ROS) (Zhang et al., 2010). These ROS may cause damage to cell membranes, proteins, DNA replication and repair. Cadmium is not redox-active metal and cause ROS generation and oxidative stress via indirect mechanisms (Srivastava and Dubey, 2012). This metal deplete cell's major antioxidants particularly thiol containing antioxidants and enzymes (Sharma et al., 2012).

Nano-particles are introduced in a growing number of commercial products. Among them, $\mathrm{TiO}_{2}$ nano-particles are one of the most produced $\mathrm{TiO}_{2}$ nano-particles in the world (Breckle, 1991). Titanium has significant biological effects on plants, being beneficial at low and toxic at higher concentrations. Although titanium is not toxic for animals and humans, its effects on plants and bacteria show noteworthy concentration dependence. Whereas for bacteria it acts as an antibiotic (Yaghoubi et al., 2000), for plants, it shows beneficial effects on various physiological parameters at low doses [e.g. biomass yield (Pais, 1993), essential element contents (Giménez et al., 1990), chlorophyll contents (Carvajal et al., 1994) and is toxic at higher ones [chlorosis, retardation of growth (Hruby et al., 2002)]. The positive effects of titanium treatment were found on rape plant development (an increase of chlorophyll content and photosynthesis rate), the yield and thousand-seed weight of winter wheat, and the yield and sugar content of sugar beets (Grenda, 2003). Plants interact with their atmospheric and edaphic environments strongly and are expected to be affected by engineered nano-particles (Ruffini-Castiglione and Cremonini, 2009). In this regard, Lu and co-workers (2002) have shown that a combination of nano-sized $\mathrm{SiO}_{2}$ and $\mathrm{TiO}_{2}$ increases the nitrate reductase enzyme in soybean (Glycine max) and improves plants abilities to absorb and utilize water and fertilizer. In addition, promotes antioxidant system, during germination and growth. Moreover, it has been found that $\mathrm{TiO}_{2}$ nano-particles encourage spinach (Spinacia oleracea) seed germination and plant growth (Zheng et al., 2005). Navarro and co-workers, (2008) stated that engineered nano-particles could sequester nutrients on their surfaces and thus serve as a nutrient stock to the organisms, particularly those engineered nano-particles having high 
specific surface area. Relatively few mechanisms have been demonstrated that explain the increased tolerance to environmental stresses of plants treated with bacteria of the genus Pseudomonas. These bacteria can facilitate plant growth indirectly by reducing plant pathogens, or directly by facilitating the uptake of nutrients from the environment, by influencing phytohormone production (e.g. auxin, cytokinin and gibberellins), by enzymatic lowering of plant ethylene levels and/or by production of siderophores (Glick et al., 1997; Kohler et al., 2006). Considering the above states, an experiment was performed to study the combined effects of titanium leaf application and bio fertilizers on antioxidant enzymes activity and some agronomic and physiological attributes in triticale.

\section{Materials and Methods}

\subsection{Study site and climate}

The experiment was undertaken at the Agricultural Research farm in Islamic Azad University, Varamin-Pishva branches, Tehran, Iran in 2015. Study site was situated at $31^{\circ} 51^{\prime} \mathrm{E}$ and $20^{\circ} 59^{\prime} \mathrm{N}$ and $1050 \mathrm{~m}$ above sea level.

\subsection{Experimental design and treatments}

A completely randomized design arranged in a $4 \times 4$ factorial experiment, with three replications was used. The experimental factors included four levels of titanium (control, bulk titanium $0.01 \%$ and $0.02 \%$ titanium nanoparticles) and four levels of bio-fertilizers (no bio-fertilizer application, Azotobacter chroococcum, Azospirillum brasilense and Azorhizobium caulinodans). Triticale seeds were treated with bacterial suspension of ( $72 \mathrm{~h}$ old, density $2-5 \times 10^{8} \mathrm{CFU} \mathrm{ml}{ }^{-1}$ ) for $30 \mathrm{~min}$ before sowing. Ten seeds were sown in $30 \times 30 \mathrm{~cm}$ plastic pots filled with soil. The $\mathrm{CdCl}_{2}$ (80 $\mathrm{mg} \mathrm{kg}^{-1}$ of soil) was mixed into the soil before potting.

\subsection{Titanium foliar application}

Titanium dioxide nano-particles and titanium oxide (bulk) were sprayed on the plants by a calibrated pressurized backpack sprayer (20 I) at stem elongation and flowering stages. Control plants were treated by distilled water.

\subsection{Sampling and data collection}

At the seed filling stage, flag leaves were collected and immediately frozen in liquid nitrogen and stored at -80 o $\mathrm{C}$ until laboratory analyses. At maturity stage, plants were harvested at soil surface and seeds were collected and weighted. Grain yield per plant was determined. All the leaves were dried for $48 \mathrm{~h}$, at $85^{\circ} \mathrm{C}$, in laboratory oven, for determining cadmium contents. Leaves and seed samples were separately digested by $\mathrm{HNO}_{3}$ and $\mathrm{HClO}_{4}$ in tubes placed on an A1 block brought gradually to $205^{\circ} \mathrm{C}$. Cd was determined by atomic absorption spectrophotometry, using an ICP-AES atomic absorption spectrophotometer (Inductively Coupled Plasma Atomic Emission Spectroscopy, SPS 1200VR, Seiko, Japan).

\subsection{Determination of chlorophyll content in leaf extract}

Chlorophyll was extracted in $80 \%$ acetone from the leaf samples according to the method of Arnon (1949). Extracts were filtrated and content of total chlorophyll was determined by spectrophotometry at 645 and $663 \mathrm{~nm}$, respectively. The content of chlorophyll was expressed as $\mathrm{mg} \mathrm{g}^{-1}$ fresh weight according to the following equation (Arnon, 1949).

$$
\text { Total chlorophyll }=[20.2(\mathrm{D} 645)+8.02(\mathrm{D} 663)] \frac{\mathrm{V}}{1000 \mathrm{~W}}
$$

\subsection{Antioxidant enzyme activity}

Superoxide dismutase (EC 1.15.1.1) activity was determined by measuring the ability of the enzyme extract to inhibit the photochemical reduction of nitro blue tetrazolium according to the method of Giannopolitis and Ries, (1977). The reaction mixture contained $100 \mu \mathrm{l} / \mu \mathrm{m}$ riboflavin, $100 \mu \mathrm{l} 12 \mathrm{mM}$ L-methionine, $100 \mu \mathrm{l} 0.1 \mathrm{mM}$ EDTA (pH 7.8), $100 \mu \mathrm{l} 50$ mM Na $2 \mathrm{CO}_{3}$ (pH 10.2), $100 \mu \mathrm{l} 75$ $\mu \mathrm{M}$ nitro blue tetrazolium in 2300 nitro blue tetrazolium $25 \mathrm{mM}$ sodium phosphate buffer ( $\mathrm{pH} 6.8$ ) and $200 \mu$ l crude enzyme extract, in a final volume of $3 \mathrm{ml}$. Glass test tubes that contained the reaction mixture were illuminated with a fluorescent lamp (120 W), and identical tubes that were not illuminated served as blanks. After illumination for 15 min, absorbance was measured at $560 \mathrm{~nm}$. One unit of SOD activity was defined as the amount of enzyme which caused $50 \%$ inhibition of photochemical reduction of nitro blue tetrazolium.

Catalase (EC 1.11.1.6) activity was estimated by the method of Cakmak and Horst, (1991). The reaction mixture contained $100 \mu \mathrm{l}$ crude extract, $500 \mu \mathrm{l} 10 \mathrm{~mm} \mathrm{H} \mathrm{H}_{2}$ and $1400 \mu \mathrm{l} 25 \mathrm{~mm}$ sodium phosphate buffer. The decrease in the absorbance recorded at $240 \mathrm{~nm}$ for $1 \mathrm{~min}$ by a spectrophotometer.

The level of membrane damage was determined by measuring MDA as the end product of peroxidation of membrane lipids (De Vos et al., 1991). In brief, samples were homogenized in an aqueous solution of trichloroacetic acid $(10 \% \mathrm{w} / \mathrm{v})$, and aliquots of filtrates were heated in $0.25 \%$ thio-barbituric acid to $100{ }^{\circ} \mathrm{C}$, for $30 \mathrm{~min}$. The amount of MDA was determined from the absorbance at $532 \mathrm{~nm}$, followed by correction for the non-specific absorbance at $600 \mathrm{~nm}$. The content of MDA was determined using the extinction coefficient of MDA $\left(\varepsilon=155 \mu \mathrm{M}^{-1} \mathrm{~cm}^{-1}\right)$.

\subsection{Statistical analysis}

All data were analysed from analysis of variance using the GLM procedure in SAS (SAS Institute Inc., 2002). The assumptions of the variance analyses were tested by checking if the residuals were random, homogenous, with a normal distribution and a mean of about zero. The significance of differences among means was carried out using Duncan's multiple range test at $p<0.05$.

\section{Results and Discussion}

The main effects of titanium concentration and biofertilizer were significant on all measured traits however, the main effect of bio-fertilizer was not significant on leaf cadmium concentration and MDA content (Table 1). The results revealed that the interaction between titanium 
concentration and bio-fertilizer was significant on grain yield, 1000-grain weight and total chlorophyll content. In general, titanium application could increase grain yield and 1000 -grain weight (Table 2 ) but $0.02 \%$ titanium dioxide nano-particle application was more effective to improve yield and yield components (Table 2). The highest grain yield was obtained when stressed plants were treated with $0.02 \%$ titanium dioxide nano-particle (Table 3 ).

The results suggest that titanium increases triticale growth, yield and yield components. Among different titanium treatments titanium dioxide nano-particle at $0.02 \%$ concentration, produced the highest yield and yield components. Zheng and co-workers, (2005) demonstrated that titanium nano-particles helped the water absorption in spinach and improved growth. The results of Zheng and co-workers, (2005) showed that spinach growth greatly improved by applying 250-4,000 ppm nano-titanium dioxide. In addition, particle size is an important factor affecting particle absorption by plants. Since titanium oxide (bulk) has greater size than titanium dioxide nano-particles it could not absorbed by plants easily rather than nanoparticles. This is in agreement with Zheng and co-workers, (2005) who reported that the significant effect of titanium nano-particles on spinach is probably attributed to the small particle size, which allows its penetration into the seed during the treatment period. It seems that bulk titanium could not penetrate into the plants; therefore, the results were not as marked as those of the nano-particles treatments. Increase in growth and yield may be due to positive effects of titanium in different cellular mechanisms, for instance improve of photosynthesis and increase in chlorophyll content are two possible reasons for this. Owolade and co-workers, (2008) reported that grain yield of cowpea (Vigna unguiculata Walp) increased when treated (as foliar application) with nano-sized titanium dioxide. They concluded that it may be due to the photocatalyst ability of the nano-sized titanium dioxide which leads to an increased photosynthetic rate. Similar yield increases were reported in rice with corresponding reduction in the incidence Curvularia leaf spot and bacteria leaf blight disease (Chao et al., 2005). In addition, the maximum grain yield and 1000 -grain weight were obtained when Azorhizobium was applied (Table 2 and 3). Gupta and co-workers (2002) showed that bacterial inoculation protected the plants against the inhibitory effects of heavy metals. It is likely that the siderophore-producing and Psolubilizing isolates might have helped plant root proliferation and enhanced the uptake of soil minerals such as $\mathrm{Fe}$ and $\mathrm{P}$ by the host plant. The other possible mechanism of plant growth promotion is the microbial production of indole acetic acid (IAA). The IAA produced by bacteria promotes root growth by directly stimulating plant cell elongation or cell division (Glick et al., 1998). In addition, the results demonstrated that the highest $\mathrm{Cd}$ concentration in leaf and grain was observed when triticale plants treated by $0.02 \%$ titanium dioxide (Table 2). Su and co-workers, (2008) showed that titanium dioxide nanoparticles increased assimilate translocation by improving the structure of chlorophyll pigments and absorbing more light. Furthermore, the highest $\mathrm{Cd}$ concentration in leaf and grain belong to Azorhizobium inoculation treatment. The present study showed that bacteria appear to increase the plant's potential for $\mathrm{Cd}$ phytoremediation because they protect the plant against metal inhibition and facilitate $\mathrm{Cd}$ accumulation. The present study showed that bacterial inoculation could enhance metal tolerance in triticale, which might be explained by the production of siderophores by bacteria which contain the 1aminocyclopropane-1-carboxylate ACC deaminase enzyme, protecting the plants against heavy metal toxicity by decreasing the level of ethylene stress (Burd et al., 1998). The lowest chlorophyll content was found in non titanium treated plants (Table 2 and 3). While the highest chlorophyll content was observed in plants treated by $0.02 \%$ titanium dioxide (Table 2 and 3 ). It has been confirmed that heavy metals affect photosystems' functions (Yang et al., 2006). It has been shown that chlorophyll related proteins, which transfer protons in PSII, were decomposed and decreased under heavy metal stress (Peng and Wang, 1991). When soil is contaminated with heavy metals, this leads to an increase in ROS generation in chloroplasts, which destroys chlorophyll molecules, reduces photosynthesis and growth. Ouzounidou, (1995) concluded that the chlorophyll synthesis can be significantly reduced in plants cultivated in soils contaminated by heavy metals. Previous results have revealed that nano- $\mathrm{TiO}_{2}$ particles at appropriate doses decrease $\mathrm{H}_{2} \mathrm{O}_{2}$ accumulation, which subsequently prevent chlorophyll degradation and or stimulate its biosynthesis. This phenomenon may protect photosynthetic processes of stressed plants.

According to Priyadarshini and co-workers, (2012) nanosilver particles at $100 \mathrm{mg} \mathrm{l}^{-1}$ increased the chlorophyll $a$ and total chlorophyll content in Brassica juncea seedlings up to 40 and $25 \%$, respectively. They reported that improved quantum efficiency in the leaves of treated seedlings significantly correlates with higher pigments values. Enhanced chlorophyll and carotenoids contents of the some plants through different nano-materials application were previously reported in Pelargonium zonale cultivars with nano-silver (Hatami and Ghorbanpour, 2014), in maize (Zea maize) with magnetic nano-particles (Racuciu and Creanga, 2006), and in Pelargonium graveolens with nano$\mathrm{TiO}_{2}$ particles (Ghorbanpour and Hatami, 2015). Moreover, the results showed that the highest total chlorophyll was obtained from Azorhizobium inoculation treatment.

In summary, the results of this study showed that the application of Azorhizobium improves triticale growth and production. The highest SOD activity and CAT activity were observed in those plants which were treated by $\mathrm{TiO}_{2}$ and $0.02 \%$ titanium dioxide (Table 2 ). Indicating that SOD plays an important role in decreasing deleterious effects of induced oxidative stress due to heavy metal stress.

It has been reported that titanium dioxide nano-particles can provoke SOD, CAT and glutathione peroxidase activity and conserve plants against free oxygen radicals (Su et al., 2008).

Nano-particles improve root ability in water and nutrient absorption and enhance antioxidant capacity in soybean 
plants (Harrison, 1996). The results are in agreement with other researches (Zheng et al., 2008; Hong et al., 2005). The increase in SOD activity may also confirm the increased production of superoxide radicals mediated by heavy metal stress. In addition, the result showed that the lowest SOD activity and CAT activity were observed control condition (Table 2). It appears that nitrogen-fixing bacteria reduce ROS production and ultimately reduce the antioxidant enzymes activity in plants (Reddy et al., 2004). Malondialdehyde content significantly reduced due to titanium application so that in $0.02 \%$ nano-particles treatment, the MDA content was lower than that in $0.01 \%$, bulk or control treatments (Table 2). As mentioned earlier, activity of SOD and CAT has been boosted in response to titanium application. As a result, accumulation of MDA lessened due to induction of plant antioxidant systems (Lei et al., 2008). Reduction in MDA content may be due to positive effect of titanium to help antioxidant system for scavenging or neutralizing of ROS. This finding proves that titanium is involving in lipid peroxidation and membrane stability process (Tohidi Moghaddam and Madani, 2016).

Table 1. Analysis of variance on some agronomic and physiological traits of triticale as affected by nano-particles titanium and bio-fertilizers

\begin{tabular}{|c|c|c|c|c|c|c|c|c|c|}
\hline S.O.V & df & $\begin{array}{l}\text { Grain } \\
\text { yield }\end{array}$ & $\begin{array}{c}\text { 1000-grain } \\
\text { weight }\end{array}$ & $\begin{array}{c}\text { Leaf } \\
\text { Cd }\end{array}$ & $\begin{array}{c}\text { Grain } \\
\text { Cd }\end{array}$ & $\begin{array}{c}\text { Total } \\
\text { chlorophyll }\end{array}$ & $\begin{array}{c}\text { Superoxide } \\
\text { dismutase }\end{array}$ & Catalase & Malondialdehyde \\
\hline Titanium & 3 & $* *$ & $* *$ & $* *$ & $* *$ & $* *$ & $* *$ & $* *$ & $* *$ \\
\hline Bio-fertilizer & 3 & $*$ & $*$ & ns & $* *$ & $* *$ & $* *$ & $* *$ & ns \\
\hline $\begin{array}{l}\text { Titanium } \times \text { Bio- } \\
\text { fertilizer }\end{array}$ & 9 & $* *$ & $* *$ & ns & ns & $* *$ & ns & ns & ns \\
\hline C.V (\%) & & 4.12 & 7.69 & 4.11 & 3.02 & 2.12 & 5.84 & 1.61 & 2.24 \\
\hline
\end{tabular}

*** and ns significant at $0.05,0.01$ percentage and no significant

Table 2. Main effects of titanium treatments and bio-fertilizers on some agronomic and physiological traits of triticale

\begin{tabular}{|c|c|c|c|c|c|c|c|c|}
\hline Treatment & $\begin{array}{l}\text { Grain yield } \\
\text { (g per } \\
\text { plant) }\end{array}$ & $\begin{array}{c}\text { 1000- } \\
\text { grain } \\
\text { weight (g) }\end{array}$ & $\begin{array}{l}\text { Leaf Cd (mg } \\
\left.\qquad \mathrm{kg}^{-1}\right)\end{array}$ & $\begin{array}{l}\text { Seed Cd } \\
\left(\mathrm{mg} \mathrm{kg}^{-1}\right)\end{array}$ & $\begin{array}{c}\text { Total } \\
\text { chlorophyll } \\
\left(\mathrm{mg} \mathrm{g}^{-1}\right. \\
\text { FW) } \\
\end{array}$ & $\begin{array}{c}\text { Superoxide } \\
\text { dismutase } \\
\left(\Delta \mathrm{A} \mathrm{mg} \text { pro } \mathrm{min}^{-1)}\right.\end{array}$ & 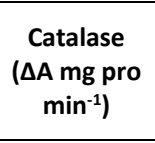 & $\begin{array}{l}\text { Malondialdehyde } \\
\left(\mathrm{nmol} \mathrm{g}^{-1} \mathrm{FW}\right)\end{array}$ \\
\hline \multicolumn{9}{|l|}{ Titanium } \\
\hline Control & $6.43 c$ & $24.15 c$ & $28.23 d$ & $2.81 \mathrm{~d}$ & $1.68 \mathrm{~d}$ & $726.17 \mathrm{c}$ & $128.18 d$ & $8.85 a$ \\
\hline Bulk titanium & $8.87 \mathrm{~b}$ & $26.12 b$ & $35.34 c$ & $3.49 c$ & $1.77 \mathrm{c}$ & $742.00 c$ & $155.78 c$ & $7.45 b$ \\
\hline $\begin{array}{l}\text { Titanium dioxide } \\
0.01\end{array}$ & $10.69 a$ & $28.35 a$ & $39.95 b$ & $4.15 b$ & 1.83.b & $866.68 b$ & $221.95 b$ & $5.20 c$ \\
\hline $\begin{array}{l}\text { Titanium dioxide } \\
0.02\end{array}$ & $10.71 a$ & $28.2 a$ & $43.91 a$ & $5.32 a$ & $1.92 a$ & $947.65 a$ & $251.98 a$ & $4.82 \mathrm{~d}$ \\
\hline \multicolumn{9}{|l|}{ Bio-fertilizers } \\
\hline Non bio fertilizer & $7.26 c$ & $23.91 d$ & $36.43 a$ & $3.58 \mathrm{c}$ & $1.69 \mathrm{~d}$ & $843.40 a$ & $214.12 a$ & 8.63a \\
\hline Azotobacter & $9.64 c$ & $27.00 c$ & $37.26 a$ & $4.05 b$ & $1.77 \mathrm{c}$ & $833.54 a b$ & 198.48a & $8.54 a$ \\
\hline Azospirillum & $9.77 a$ & $27.41 b$ & $36.75 a$ & $3.83 \mathrm{~b}$ & $1.85 \mathrm{~b}$ & $816.57 b$ & $179.69 b$ & $8.50 a$ \\
\hline Azorhizobium & $10.06 a$ & $27.92 a$ & $36.99 a$ & $4.31 \mathrm{a}$ & $1.90 \mathrm{a}$ & $789.00 c$ & $165.58 \mathrm{c}$ & $8.70 a$ \\
\hline
\end{tabular}

Treatment means followed by the same letter within each common are not significantly different $(P<0.05)$ according to Duncan's Multiple Range test

Table 3. Interaction between titanium treatments and bio-fertilizers on some agronomic and physiological traits of triticale

\begin{tabular}{|c|c|c|c|c|c|c|c|c|c|}
\hline Titanium & Bio-fertilizers & $\begin{array}{l}\text { Grain } \\
\text { yield } \\
\text { (g per } \\
\text { plant) } \\
\end{array}$ & $\begin{array}{l}\text { 1000- } \\
\text { grain } \\
\text { Weight } \\
\text { (g) }\end{array}$ & $\begin{array}{l}\text { Leaf Cd } \\
\left(\mathrm{mg} \mathrm{kg}^{-1}\right)\end{array}$ & $\begin{array}{l}\text { Grain Cd } \\
\left(\mathrm{mg} \mathrm{kg}^{-1}\right)\end{array}$ & $\begin{array}{c}\text { Total } \\
\text { chlorophyll } \\
\left.\text { (mg g }{ }^{-1} \mathrm{FW}\right)\end{array}$ & $\begin{array}{c}\text { Superoxide } \\
\text { dismutase } \\
(\Delta \mathrm{A} \mathrm{mg} \mathrm{pro} \\
\left.\min ^{-1}\right)\end{array}$ & $\begin{array}{c}\text { Catalase } \\
\text { ( } \Delta \mathrm{A} \text { mg pro } \\
\left.\mathrm{min}^{-1}\right)\end{array}$ & $\begin{array}{c}\text { Malondialdehyde } \\
\text { (nmol g-1 FW) }\end{array}$ \\
\hline \multirow{5}{*}{ Control } & Control & $4.85 \mathrm{~h}$ & $20.8 f$ & $23.81 \mathrm{i}$ & $2.03 \mathrm{j}$ & $1.39 \mathrm{fg}$ & 811.90ab & $251.96 a$ & $8.60 a$ \\
\hline & Azotobacter & $6.88 \mathrm{~g}$ & $25.4 \mathrm{e}$ & 24.14ih & $2.30 \mathrm{i}$ & $1.42 f$ & $778.87 \mathrm{cb}$ & $200.83 b c$ & $8.57 a$ \\
\hline & Azospirillum & $6.91 \mathrm{fg}$ & $24.8 d$ & 24.31gh & $2.42 \mathrm{hi}$ & $1.46 f$ & $754.47 \mathrm{~cd}$ & $183.41 \mathrm{~cd}$ & $8.55 a$ \\
\hline & Azorhizobium & $7.11 f$ & $25.6 c$ & $24.57 \mathrm{~g}$ & $2.57 \mathrm{~h}$ & $1.51 \mathrm{e}$ & $736.88 \mathrm{~cd}$ & $76.26 \mathrm{dc}$ & $8.37 \mathrm{~b}$ \\
\hline & Control & $7.24 f$ & $23.9 \mathrm{~cd}$ & $29.69 f$ & $2.83 \mathrm{~g}$ & $1.54 \mathrm{e}$ & $848.94 a$ & $226.15 a b$ & $7.56 \mathrm{c}$ \\
\hline \multirow{3}{*}{$\begin{array}{c}\text { Bulk } \\
\text { titanium }\end{array}$} & Azotobacter & $9.33 c$ & $26.8 b$ & $30.47 e$ & $2.87 \mathrm{~g}$ & $1.59 \mathrm{de}$ & $814.34 a b$ & $147.23 \mathrm{ef}$ & $7.45 c$ \\
\hline & Azospirillum & $9.36 c$ & $26.7 b$ & $30.32 \mathrm{e}$ & $3.19 f$ & $1.63 d$ & $659.01 \mathrm{e}$ & 118.20fgh & $7.39 d$ \\
\hline & Azorhizobium & $9.58 c$ & $27.1 b$ & $30.64 \mathrm{e}$ & $3.24 f$ & $1.68 \mathrm{~d}$ & $621.36 \mathrm{ef}$ & $97.47 \mathrm{bcd}$ & $7.44 c$ \\
\hline \multirow{4}{*}{$\begin{array}{c}\text { Titanium } \\
\text { dioxide } \\
0.01\end{array}$} & Control & $8.53 d$ & $25.6 c$ & $33.81 d$ & $3.35 \mathrm{ef}$ & $1.72 \mathrm{c}$ & $754.47 \mathrm{~cd}$ & $200.83 b c$ & $5.23 \mathrm{~g}$ \\
\hline & Azotobacter & 11.16.b & $29.3 a$ & $34.29 c$ & 3.49ed & $1.75 c$ & $736.88 \mathrm{~cd}$ & $176.26 \mathrm{dc}$ & $5.46 \mathrm{e}$ \\
\hline & Azospirillum & $11.34 b$ & 28.9ab & $34.39 c$ & $3.65 \mathrm{dc}$ & $1.78 b$ & $637.52 \mathrm{ef}$ & $135.35 \mathrm{fg}$ & $5.45 \mathrm{e}$ \\
\hline & Azorhizobium & $11.81 a$ & $29.6 a$ & $34.58 c$ & $3.80 c$ & $1.82 \mathrm{~b}$ & $642.36 \mathrm{ef}$ & $33.36 f g$ & $5.37 f$ \\
\hline \multirow{4}{*}{$\begin{array}{c}\text { Titanium } \\
\text { dioxide } \\
0.02\end{array}$} & Control & $8.43 e$ & $25.4 \mathrm{c}$ & $37.35 b$ & $4.39 b$ & $1.79 \mathrm{~b}$ & $848.94 a$ & $226.15 a b$ & $4.85 \mathrm{~h}$ \\
\hline & Azotobacter & $11.22 \mathrm{~b}$ & $28.8 a b$ & $37.71 \mathrm{ab}$ & $4.52 \mathrm{ab}$ & $1.81 b$ & 814.34ab & $251.96 a$ & $4.68 \mathrm{j}$ \\
\hline & Azospirillum & $11.48 \mathrm{ab}$ & $29.2 a$ & $37.68 \mathrm{ab}$ & 4.60ab & $1.83 \mathrm{~b}$ & 811.90ab & 197.47bcd & $4.75 i$ \\
\hline & Azorhizobium & $11.74 a$ & $29.4 a$ & 37.90a & $4.73 a$ & $1.95 a$ & $778.87 \mathrm{cb}$ & $83.41 \mathrm{~cd}$ & $4.66 j$ \\
\hline
\end{tabular}

Treatment means followed by the same letter within each common are not significantly different $(P<0.05)$ according to Duncan's Multiple Range test 
In general, although several recent studies have considered the antioxidative responses by the cell to abiotic stress and tolerance, other possible events such as non-enzymatic components that notably includes reactions linked to the intracellular ascorbic acid and glutathione in the maintenance of redox homeostasis should be taken into account.

\section{Conclusion}

The nano- $\mathrm{TiO}_{2}$ at proper concentrations could act as modifier to alleviation of deleterious effects of heavy metal stress on physiological processes through increasing antioxidant enzyme activity, which resulted in reduced lipid peroxidation and stability of chlorophyll pigments. The nano- $\mathrm{TiO}_{2}$ at proper concentrations increased triticale yield under $\mathrm{Cd}$ stress. The application of bio-fertilizers could reduce the harmful effects of ROS and improve triticale tolerance to Cd contamination.

\section{ACKNOWLEDGMENT}

The author would like to thank Islamic Azad University for funding this project

\section{REFERENCES}

Arnon D.I. (1949), Copper enzymes in isolated chloroplasts, polyphenol oxidase in Beta vulgaris, Plant Physiology, 24, 1-150.

Breckle S.W. (1991), Growth under stress. Heavy metals. In: Waisel, Y., Eshel, A., Kafkafi, U. (Eds.), Plants roots: the hidden half. M. Dekker, Inc. New York, USA, pp. 351-373.

Burd G.I., Dixon D.G. and Glick. B.R. (1998), A plant growth promoting bacterium that decreases nickel toxicity in plant seedlings, Applied and Environmental Microbiology, 64, 3663-3668.

Cakmak I. and Horst W. (1991), Effect of aluminium on lipid peroxidation, superoxide dismutase, catalase and peroxidase activities in root tip of soybean (Glysin max), Plant Physiology, 83, 463-468.

Carvajal M.F., Martínez-Sánchez F. and Alcaraz C.F. (1994), Effect of Ti (IV) on some physiological activity indicators of Capsicum anuum L. plants, Journal of Horticultural Science, 69, 427-432.

Chao S.H.L. and Choi. H.S. (2005), Method for providing enhanced photosynthesis. Korea Research Institute of Chemical Technology, Jeonju, South Korea. Bulletin 10pp

De Vos C., Schat H., De Waal M.A.M., Vooijs R. and Ernst W.H.O. (1991), Increased resistance to copper-induced damage of the root plasma membrane in copper tolerant Silene cucubalus, Physiologia Plantarum, 82, 523-528.

Ghorbanpour M. and Hatami M. (2015), Changes in growth, antioxidant defense system and major essential oils constituents of Pelargonium graveolens plant exposed to nano-scale silver and thidiazuron, Indian Journal of Plant Physiology, 20, 116-123.

Giannopolitis C. and Ries S. (1977), Superoxide dismutase occurrence in higher plant, Plant Physiology, 59, 309-314.

Giménez J.L., Martínez-Sánchez F., Moreno A., et al. (1990), Titanium in plant nutrition. III. Effect of Ti (IV) on yield of Capsicum anuum, L., in Proceedings of III Symposium Nacional de Nutrición Mineral de las Plantas, SPIC-UIB, eds., Nutrición Mineral bajo condiciónes de Estrés, pp. 123-128.
Glick B.R., Liu C., Ghosh S. and Dumbrof E.B. (1997), Early development of canola seedlings in the presence of the plant growth-promoting rhizobacterium Pseudomonas putida GR12-2, Soil Biology and Biochemistry, 29, 1233-1239.

Glick B.R., Penrose D.M. and Li J. (1998), A model for the lowering of plant ethylene concentrations by plant growth promoting bacteria, Journal of Theoretical Biology, 190, 63-68.

Grenda A. (2003), Tytanit - aktywator procesów metabolicznych [Tytanit - an activator of metabolic processes]. In: Chemicals in sustainable agriculture. Czech Republic, 4, 263-269.

Gupta A., Meyer J.M. and Goel R. (2002), Development of heavy metal resistant mutants of phosphate solubilizing Pseudomonas sp. NBRI4014 and their characterization, Current Microbiology, 45, 323-327.

Harrison C.C. (1996), Evidence for intra-mineral macromolecules containing protein from plant silicas, Phytochemistry, 41, 37-42.

Hatami M. and Ghorbanpour M. (2014), Defense enzymes activity and biochemical variations of Pelargonium zonale in response to nano-silver particles and dark storage, Turkish Journal of Biology, 38, 130-139.

Hong F.S., Yang P. and Gao F.Q. (2005), Effect of Nano-TiO2 on spectral characterization of photosystem II particles from spinach, Chemical Researches in Chinese Universities, 21, 196-200.

Hruby M., Cígler P. and Kuzel S. (2002), Titanium in plant nutrition. The contribution to understanding the mechanism of titanium action in plants, Journal of Plant Nutrition, 25, 577-598.

Kohler J., Caravaca F., Carrasco L. and Roldn A. (2006), Contribution of Pseudomonas mendocina and Glomus intraradices to aggregates stabilisation and promotion of biological properties in rhizosphere soil of lettuce plants under field conditions, Soil Use and Management, 22, 298-304.

Lei Z., Su M.Y., Wu X., Liu C., Qu C.X., Chen L., Huang H., Liu X.Q. and Hong F.S. (2008), Antioxidant stress is promoted by nanoanatase in spinach chloroplasts under UV-Beta radiation, Biological Trace Element Research, 121, 69-79.

Lu C.M., Zhang C.Y., Wen J.Q. and Tao M.X. (2002), Research of the effect of nanometer on germination and growth enhancement of Glycine max and its mechanism, Soybean Science, 21, 168-172.

Muradoglu F., Gundogdu M., Ercisli S., Encu T., Balta F., Jaafar H.Z.E. and Zia-UI-Haq M. (2015), Cadmium toxicity affects chlorophyll $\mathrm{a}$ and $\mathrm{b}$ content, antioxidant enzyme activities and mineral nutrient accumulation in strawberry, Biological Research, 48, 11.

Navarro E., Baun A., Behra R., Hartmann N.B, Filser J., Miao A., Quigg A., Santschi P.H. and Sigg L. (2008), Environmental behavior and ecotoxicity of engineered nanoparticles to algae, plants, and fungi, Ecotoxicology, 17, 372-386.

Ouzounidou G. (1995), Cu-ions mediated changes in growth, chlorophyll and other ion contents in a $\mathrm{Cu}$ - tolerant Koeleria splendens, Biologia Plantarum, 37, 71-78.

Owolade O.F., Ogunleti D.O. and Adenekan M.O. (2008), Titanium dioxide affected diseases, development and yield of edible cowpea, Electronic Journal of Environmental, Agricultural and Food Chemistry, 7, 2942-2947.

Pais I. (1983), The biological importance of titanium, Journal of Plant Nutrition, 6, 3-131. 
Peng M. and Wang H. (1991), The variation of cell ultra-structure of maize (Zea mays L.) seedlings, China Environmental Science, 11, 426-431.

Priyadarshini S., Deepesh B., Zaidi M.G.H., PardhaSaradhi P., Khanna P.K., and Arora S. (2012), Silver nanoparticlemediated enhancement in growth and antioxidant status of Brassica juncea, Applied Biochemistry and Biotechnology, 167, 2225-2233.

Racuciu M. and Creanga D. (2006), TMA-OH coated magnetic nanoparticles internalized in vegetal tissue, Romanian Journal of Physics, 52, 395-402

Reddy A.R., Chaitanya K.V. and Vivekanandan M. (2004), Droughtinduced responses of photosynthesis and antioxidant metabolism in higher plants, Journal of Plant Physiology, 161, 1189-1202.

Ruffini Castiglione M. and Cremonini R. (2009), Nanoparticles and higher plants, Caryologia, 62, 161-165.

Sandalio L.M., Dalurzo H.C., Gomez M., Romero-Puertas M.C. and Del Rio L.A. (2001), Cadmium-induced changes in the growth and oxidative metabolism of pea plants, Journal of Experimental Botany, 52, 2115-2126.

SAS Institute Inc. (2002), The SAS System for Windows, Release 9.0. Statistical Analysis Systems Institute, Cary, NC, USA.

Satyakala G. (1997), Studies on the effect of heavy metal pollution on Pistia stratiotes (water lettuce), Indian Journal of Environment and Health, 39, 1-7.

Sharma P., Jha A.B., Shanker Dubey R. and Pessarakli M (2012), Reactive Oxygen Species, Oxidative Damage, and Antioxidative Defense Mechanism in Plants under Stressful Conditions, Journal of Botany, 2012, ID 217037, 26 pages

Su M., Liu C., Qu C., Zheng L., Chen L., Huang H., Liu X., Wu X. and Hong F. (2008), Nano-anatase relieves the inhibition of electron transport caused by linolenic acid in chloroplasts of spinach, Biological Trace Element Research, 122, 73-81.

Srivastava R.K. and Dubey R.S. (2012), Metal toxicity, production of reactive oxygen species and their consequences in plants. In: Hemantaranjan A (ed) Advances in plant physiology, vol 13. Scientific Publishers, Jodhpur, pp 415-456.

Tohidi Moghaddam M. and Madani A. (2016), Influence of titanium foliar application on antioxidant enzyme activity and some biochemical attributes of corn, Maydica, 61.3- M23.

Yaghoubi S., Schwietert W. and McCue J.P. (2000), Biological roles of titanium, Biological Trace Element Research, 78, 205-217.

Yang F., Hong F.S., You W.J, Liu C., Gao F., Wu C. and Yang P. (2006), Influences of nano-anatase $\mathrm{TiO}_{2}$ on the nitrogen metabolism of growing spinach, Biological Trace Element Research, 110, 179-190.

Zhang Z.C., Chen B.X. and Qiu B.S. (2010), Phytochelatin synthesis plays a similar role in shoots of the cadmium hyperaccumulator Sedum alfredii as in non-resistant plants, Plant, Cell and Environment, 33, 1248-1255.

Zheng L., Hong F., Lu S. and Liu C. (2005), Effect of nano-TiO2 on strength of naturally aged seeds and growth of spinach, Biological Trace Element Research, 105, 83-91.

Zheng L., Su M.Y., Wu X., Liu C., Qu C.X., Chen L., Huang H., Liu X.Q. and Hong F.S. (2008), Antioxidant stress is promoted by nano-anatse in spinach chloroplast under UV-B radiation, Biological Trace Element Research, 121, 69-79. 